\title{
Source of Information About Environmental Awareness in Growing Green Ethos For Junior High School Students in Bandung, Indonesia
}

\author{
Hanny Hafiar ${ }^{1}$, Diana Harding ${ }^{2}$, Anissa Lestari Kadiyono ${ }^{3}$, Titin Nurhayati Ma'mun ${ }^{4}$, Ahmad \\ Gimmy Prathama Siswadi ${ }^{5}$, Yus Nugraha, Hery Wibowo ${ }^{6}$ \\ Padjadjaran University, Bandung, Indonesia ${ }^{1-6}$ \\ \{hanny.hafiar@unpad.ac.id $\left.{ }^{1}\right\}$
}

\begin{abstract}
Environmental issues have become global issues. Environmental damage caused by human activities has entered an alarming stage, which is basically more due to the nescience of the community to protect the environment. This nescience is also triggered by the lack of individual understanding of the importance of protecting the environment. Therefore, it is necessary to conduct environmental awareness activities to the community through counseling activities that take the Green Ethos theme. The target object of this counseling activity is junior high school students. The method used in this research is the description method, as an initial step to identify sources of information that form the understanding and environmental awareness possessed by the object of research. Data collection techniques used were using observation techniques and focus group discussions. The results show that the understanding and awareness of junior high school students in the city of Bandung tend to be formed from information obtained from friends, non-formal education, mass media, internet media, internet media, parents and teachers. However, there are a number of obstacles that become resistors for them to be able to actively participate in protecting the environment, among others are the availability of facilities such as a trash can that has been categorized, making it easier for students to dispose of waste according to their type, lack of available drinking water in public facilities to reduce the consumption of plastic beverage waste in packaging, as well as eating and drinking habits on the street or other public facilities which only provide minimal trash can
\end{abstract}

Keywords: Environmental, Awareness, Issues

\section{Introduction}

Environmental sustainability is important for human life because human life in various parts of the world is very dependent on natural and environmental conditions. Therefore, sustainability has become a central point on the global stage [1]. There are various natural damages that threaten human survival. Damages in the form of natural disasters such as floods, landslides, and coastal abrasion, are mostly caused by human activities. Natural disasters caused by human activities can be avoided if people have an understanding of environmental conservation around them. Therefore, education is needed in the form of information 
dissemination on disaster and environmental issues as a solution and prevention [2], to various levels of society, especially the younger generation, as future natural heirs.

Educational activities in the form of information dissemination on environmental awareness are expected to shape environmental care behavior. Environmental care behavior is the ability to make choices about how to behave and respond based on impulses of encouragement. Environmental care behavior is part of the action that results from people's knowledge of the environment [3]. There have been many similar activities carried out in Indonesia, as an effort to shape environmental health care behaviors, but so far efforts to improve behavior based on awareness of health and the environment have not shown optimal results [4]. Nevertheless, educational efforts are indeed an effort that must be carried out continuously and progressively because the results of education are results that can only be achieved on a long-term scale.

Education to increase environmental awareness is an effort that must be done by involving the community in its development. Community development can be done to gather bottom-up ideas of change, including those related to local wisdom around ideas which value local knowledge, local culture, local resources, local skills, and local processes [5]. Moving the community so they are willing to play an active role in environmental conservation is a social responsibility that must be carried out together.

Social responsibility activities are intended to increase public awareness of a social problem or to support a particular activity, including raising funds, participation from the community, or in the context of recruiting volunteers to jointly overcome these social problems [6]. This means that in empowering activities, individuals and society not only become passive objects (targets) but also become the subjects (actors) [7]. However, an initiator still needs to be able to mobilize the community to be willing to act in the interests of the community, such as extension activists as facilitators who can disseminate information about nature conservation to increase public awareness of the importance of protecting the environment.

Through this counseling program, the community can improve their knowledge and skills according to their respective fields, because in the extension program, there are some training provided by facilitators or facilitators [8]. The facilitator will not be able to act as an agent of change if he does not get support from various parties. Related party support is needed to make the discourse of change initiated by the facilitator manifest in an activity, both formal and non-formal education activities. Forms of non-formal education can be in the form of training [9]. So that activities to increase environmental awareness can be carried out through practical and training-oriented training activities that are theoretically and conceptually oriented.

Therefore, a Green Ethos counseling activity was held by the academic community from Padjadjaran University to increase environmental awareness among students in junior high school in Bandung. This activity involves elements of visual literacy in order to provide a real picture for participants of the activity. The visual literacy activity is a continuous process which can foster knowledge that is owned by the community [10]. In addition to emphasizing the factors of extension material, this activity determines the point of stress on the communicator factor as the message source. Based on the results of previous studies, information retrieval models consisting of factors of information sources are known to influence public awareness [11].

Based on this, further research is conducted to find out the sources of information that can increase students' understanding of environmental awareness. This is done, considering that planting environmental awareness is not a process that can produce results in a short time. 
Besides that, it was realized that the extension facilitator could not play a solo role because the process of planting environmental awareness requires the role of other environmental communication communicators around the target object.

\section{Method}

There are several studies that have examined environmental education for students through several aspects, including producing the following findings and statements: Technology can improve teaching and learning [12], including learning about the environment; Green campus development as a new approach to emphasis on green environment protection [13], local wisdom-based science learning models to improve student's conservationist character [14], as well as research on student attitudes to climate change [15], based on environmental awareness.

The research uses the descriptive method by distributing questionnaires to obtain an overview of information sources that provide students with an understanding of environmental awareness. The number of respondents taken for this study is 2151 students in junior high school in the Bandung city.

\section{Results and discussions}

One of the goals of national education is to shape the character of students. Character education can be used as a strategic media to instill, develop, and nurture noble values and humanity [16], including the values of caring for the environment. Education can be in the form of guidance given by those who feel they have a responsibility for children or young people, to bring them to the level of maturity, both physical and spiritual. As for spiritual maturity, it involves aspects of the formation of responsibility [17]. It is the formation of attitudes and behaviors for environmental responsibility that are expected to grow in students through stimuli carried out in this Green Ethos counseling activity. There are many factors that influence student behavior, so it is not an easy thing to make students with enough numbers to be able to behave the same in a relatively short time [18]. Therefore, it is very unlikely if facilitators from counseling activities can play independently without assistance from other information sources that have the same goal of instilling student awareness and behavior towards the environment. Based on the calculation of the data collected, the following results are obtained:

Table 1. Sources of Information About Environmental Awareness for Students in the Bandung City

\begin{tabular}{lrr}
\hline \multicolumn{1}{c}{ Aspect } & Amount & percentage \\
\hline Friends & 1132 & $52,6 \%$ \\
Education & 1857 & $86,3 \%$ \\
Media Massa & 1598 & $74,3 \%$ \\
Media Internet & 1486 & $69,1 \%$ \\
Parent & 2003 & $93,1 \%$ \\
Teacher & 1977 & $91,9 \%$ \\
\hline
\end{tabular}




\subsection{The Role of Educational Institutions}

Educational institutions both formal and non-formal have an important role in fostering awareness and positive behavior towards the environment. Therefore, students should get education about the environment from the most basic level of education to tertiary education. Green higher education is all about creating knowledge, skills, attitudes, and values related to the environment [19]. In addition, it was also said that the implementation of green skills through the co-curriculum activities should focus on students and green development and see in practice what it means to work sustainably [20]. This means that environmental education should be implemented in the formal education curriculum in Indonesia.

As for non-formal education, planting values for the environment can be initiated and driven by change agents from various stratum society who have a concern to invite the community to participate in protecting the environment through various activity strategies. A change of model of this magnitude requires multiple mechanisms and strategies. Among them, education plays an important role. It has a mission in the framework of educating professionals and in the context of education throughout life and citizenship education [21]. It is through this community empowerment activity that extension activities can be coupled with various interactions that involve students as counseling participants with the environment. Because the interaction with the environment during the learning process will stimulate all students' senses and encourage students to learn in a creative and innovative way [22]

This kind of interactive activity can run effectively, considering there are lots of studies that indicate that the environment can improve environmental awareness, and attitudes toward maintaining the environment and preventing pollution [23]. So that environmental education can be started by moving students' awareness and behavior from small things such as participating in reducing pollution in the form of garbage in their respective environments.

\subsection{Media Roles}

For the past century, each new medium introduced - motion pictures, radio, television, cable, and the Internet - has been extolled for its revolutionary capabilities to lift the human spirit, improve education, reduce conflict, and empower the public. Such worthy aspirations were trumpeted with the appearance of social media [19]. Based on this statement, it can be seen that the media can play an active role as an educational tool that provides knowledge about the environment to foster awareness and positive behavior of the community towards the environment.

However, there are times when the media is an entity that is positioned as a friend and an opponent because socio-cultural values that prioritize the formation of noble characters through education are gradually beginning to be deemed not in accordance with the times. Students are now more fond of the Popular Culture presented by various media available in the community. In fact, each region has cultural wealth that can be developed intelligently to become the basis of character education for students in the area [20]. Therefore, it is expected that the policymakers in the media have the same goal to develop positive awareness and positive behavior of the community towards the environment through the various impressions and information content that they disseminate.

Based on the explanation, it can be said that through education, humans are expected to be more aware of the environment, education both formally and informally is done to familiarize humans with critical, rational and futuristic thinking. The role of education in the field of health and the environment is to intervene in behavioral factors so that the behavior of 
individuals, groups or communities in accordance with environmental health values [21]. In this case, educational institutions cannot play their own role, it needs the support of various parties to jointly educate the nation through the dissemination of information to the public in order to produce the next generation of people who love their environment.

\section{Conclusions}

The activity of planting public awareness that manifests in environmental care behavior requires various sources of information that play an active role according to their respective portions. Sources of information that can become agents of change that disseminate the importance of protecting the environment for junior high school students in the city of Bandung can be done through friends, formal education institutions through teachers, nonformal institutions, and parents, as well as media both mass media and the internet.

Based on these findings, it is expected that various sources of information that have been used as references by junior high school students in the city of Bandung, who are one of the nation's generation, should prepare themselves to be credible communicators. The credibility of information sources can be increased through efforts to disseminate information about protecting the environment based on intrinsic awareness and pure love for the environment.

Especially for the role of media institutions, it is expected to consider the element of environmental-based idealism in every dissemination of information through its media, because at this time, the media tends to be the main reference of adolescents in consuming information, including information about the environment. Thus, it is expected that with the active role of various parties awareness and behavior of caring for the community can be formed gradually and make every layer of society as a community capable of maintaining and preserving the environment, not the other way around.

\section{References}

[1] A. J. Irish, "An Ethos of Sustainability: Integrated Sustainability for Urban Development," Int. J. Undergrad. Res. Creat. Act., vol. 6, no. 2, p. 1022, Apr. 2014.

[2] S. Arifianto and M. R. Virhani, "Informasi Bencana Dan Budaya Lokal (Kasus Penanggulangan Banjir di Kelurahan Bukit Duri Jakarta Selatan)," Jakarta, 2009.

[3] R. Triwardani and Sarmini, "Pembudayaan Karakter Peduli Lingkungan Melalui Kegiatan Bank Sampah Di Desa Duwet Kecamatan Bendo Kabupaten Magetan,” Kaji. Moral dan Kewarganegaraan, vol. 3, no. 1, 2013.

[4] F. N. Sani, "Hubungan Tingkat Pengetahuan Sehat - Sakit Dengan Sikap Mahasiswa Universitas Muhammadiyah Surakarta Tentang Perilaku Hidup Bersih Dan Sehat,” J. KesMaDaSKa, vol. 2, no. 2, pp. 12-18, 2011.

[5] E. U. R. Nassaluka, H. Hafiar, and C. C. Priyatna, "Model Kemitraan PT. Holcim Indonesia Tbk," J. Profesi Humas, vol. 1, no. 1, pp. 22-34, 2016.

[6] R. Rakhmawati and A. Sani, "Implementasi Kegiatan Corporate Communication Oleh Divisi Corporate Secretary Pt. Bio Farma (Persero)," J. Profesi Humas, vol. 1, no. 1, pp. 40-52, 2016.

[7] U. Wahyudin and H. S. Arifin, "Sosialisasi Sanitasi Diri Dan Lingkungan Di Pesantren Salafi Melalui Pos Kesehatan Pesantren (Poskestren) Dalam Membentuk Sikap Santri Terhadap Sanitasi," J. Kaji. Komun., vol. 3, no. 2, pp. 148-153, 2015. 
[8] A. Budiono and E. Saepudin, "Literasi Informasi Masyarakat Pedesaan Dalam Program Pemberdayaan Masyarakat Di Kecamatan Cikancung Kabupaten Bandung," J. Kaji. Inf. dan Perpust., vol. 3, no. 2, pp. 221-234, 2015.

[9] A. Rahmat and I. Bakti, "Kinerja Hubungan Masyarakat (Humas) Pemerintah daerah Kabupaten dan Kota di Jawa Barat," J. Kaji. Komun., vol. 4, no. 2, pp. 133-141, 2016.

[10] M. N. Miftah, E. Rizal, and R. K. Anwar, "Pola Literasi Visual Infografer Dalam Pembuatan Informasi Grafis ( Infografis ).,” J. Kaji. Inf. dan Perpust., vol. 4, no. 1, pp. 87-94, 2016.

[11] I. Bakti, E. A. S. Dewi, R. Romli, and H. R. Budiana, "Analisis Faktor Personal Pada Sumber Komunikasi Dalam Pengelolaan Tanaman Obat Keluarga Di Jawa Barat,” J. Kaji. Komun., vol. 3, no. 2, pp. 133-139, 2015.

[12] J. Groff, "Technology-rich innovative learning environments," 2013.

[13] H. Tan, S. Chen, Q. Shi, and L. Wang, "Development of green campus in China," J. Clean. Prod., vol. 64, pp. 646-653, Feb. 2014.

[14] M. Khusniati, Parmin, and Sudarmin, "Local Wisdom-Based Science Learnıng Model through Reconstruction of Indigenous Science to Improve Student 's Conservationist Character," J. Turkish Sci. Educ., vol. 14, no. 3, pp. 16-23, 2017.

[15] R. Christensen and G. Knezek, "The climate change attitude survey: Measuring middle school student beliefs and intentions to enact positive environmental change," Int. J. Environ. Sci. Educ., vol. 10, no. 5, pp. 773-788, 2015.

[16] M. Zainuddin, "Implementasi kurikulum 2013 dalam membentuk karakter anak bangsa," Universum, vol. 9, no. 1, pp. 131-139, 2015.

[17] Jalaluddin, "Pendidikan karakter berbasis keluarga," J. Ta'dib, vol. XVII, no. 4067, pp. 41-52, 2012.

[18] H. H. Sholikhah and F. Sustini, "Gambaran Perilaku Hidup Bersih dan Sehat tentang Food Borne Disease pada Anak Usia Sekolah di SDN Babat Jerawat I Kecamatan Pakal Kota Surabaya," Bul. Penelit. Sist. Kesehat., vol. 16, no. 4, pp. 351-362, 2013.

[19] R. G. Picard, "The humanisation of media? Social media and the reformation of communication," Commun. Res. Pract., vol. 1, no. 1, pp. 32-41, 2015.

[20] A. L. Lonto, "Pengembangan Model Pendidikan Karakter Berbasis Nilai SosioKultural pada Siswa SMA di Minahasa,” J. Mimb., vol. 31, no. 2, pp. 319-327, 2015.

[21] E. U. Dewi, "Pengaruh Pendidikan kesehatan Terhadap Perilaku Hidup Bersih Dan Sehat Pada Pemulung di TPA Wonokromo Surabaya," J. Keperawatan, vol. 4, no. 1, 2015. 